\title{
The impact of Caesalpinia sappan L. powder addition on the quality attributes of white and milk chocolates
}

\author{
Elinda Okstaviyani ${ }^{1}$, Kawiji ${ }^{1}$, Raden Baskara Katri Anandhito ${ }^{2}$, Asri Nursiwi $^{1}$, and Dimas \\ Rahadian Aji Muhamnmad ${ }^{1 *}$ \\ ${ }^{1}$ Department of Food Science and Technology, Faculty of Agriculture, Universitas Sebelas Maret. Jl. \\ Ir. Sutami 36A Kentingan, Surakarta 57126 Indonesia. \\ ${ }^{2}$ Department of Agricultural Product Technology, Vocational School, Universitas Sebelas Maret. Jl. \\ Ir. Sutami 36A Kentingan, Surakarta 57126 Indonesia.
}

\begin{abstract}
Sappan wood (Caesalpinia sappan L.) is a spice that has a high polyphenol content and has the potential to enrich the chocolate taste. This study evaluated the panelists' acceptance and physical analysis (color and hardness) of white and milk compound chocolate with the addition of Sappan wood powder $(0 \%, 5 \%, 10 \%, 15 \%)$ by implementing a completely randomized design (CRD) experiment with one factor. The results showed that the addition of Sappan wood powder could reduce the panelists' preference at the parameters of color, aroma, taste, texture and overalls. Hence, Panelists preferred white and milk compound chocolate without the addition of Sappan wood powder. Results of the physical analysis showed that the addition of Sappan wood powder decreased the chocolate brightness and increased the chocolate hardness.
\end{abstract}

\section{Introduction}

Cocoa (Theobroma cacao L.) is one of among potential plantation commodities having a vital role in the Indonesian economy [1]. In 2018, Indonesia produced 240,000 tons of cocoa beans [2]. Furthermore, cocoa from Indonesia also has a good quality if it is fermented properly [3]. Cocoa is one of the commodities that are used as the main raw material in making chocolate [4]. However, according to data from International Trade Center [5] most of cocoa products in Indonesia were exported in the form of cocoa beans and semi-finished materials such as cocoa powder, cocoa butter, and cocoa paste. Meanwhile, exporting cocoa in the form of ready-to-eat chocolate products is still rare [5].

Cocoa is a source of polyphenols that are beneficial to human health. The polyphenol composition in dry cocoa beans is $\pm 15 \%$, which are dominated by epicatechins and catechins [6]. However, the process of processing fresh cocoa beans into dry cocoa beans resulted in a decrease of the polyphenol compounds. A study of Aikpokpodion and Dongo

\footnotetext{
* Corresponding Author: dimasrahadian@staff.uns.ac.id
} 
[7] suggested that the fermentation process for five days caused a decrease in the polyphenol content in cocoa beans by $52.82 \%$. Furthermore, the drying and roasting processes cause a decrease in the polyphenol content of up to $35 \%$ and $48.06 \%$ respectively [8]. Thus, the final product of chocolate has a relatively low polyphenol content.

Sappan wood powder is made from the Sappan wood bark that has been peeled off, dried, then mashed. Sappan wood powder is one of the spices that have high polyphenol levels. The main component of Sappan wood extract is brazilein which belongs to the flavonoid group [9]. According to Kumar [10], flavonoids consist of a large group of polyphenolic compounds that have a benzo- $\gamma$-pyrone structure. The hydroxyl functional groups in flavonoids provide an antioxidant effect that can detain free radicals and bind metals. The high polyphenol content in Sappan wood was discovered in the powder [10]. Many studies have shown that addition of functional ingredients could change the characteristic as well as consumer acceptance of chocolates. Thus, this study was conducted to identify the effect of panelists' acceptance level by using sensory (color, aroma, taste, texture, and overall) and physical (color, hardness, and the texture of white and milk chocolates) analysis. Further, the addition of Sappan wood powder is expected to create a chocolate-based functional food innovation.

\section{Material and method}

The materials used in this study were white and milk compound chocolate with the "Tulip" brand produced by PT Freyabadi Indotama, 120 mesh of Sappan wood powder (Caesalpinia sappan L.) obtained from Asyifa Herbal Sehat Surakarta and water. An electric stove, stainless pan and Cocoa-Town melanger, were used to make a chocolate in this study. The process of making white and milk chocolate was carried out by cutting the chocolate into small pieces and then melting them using the au brain marie method with a maximum temperature of $70^{\circ} \mathrm{C}$. Next, Sappan wood powder was added and mixed using a melanger for \pm 2.5 hours. Then, the chocolate was poured into the mold and stored in the refrigerator for 15 minutes at a temperature of $5-8^{\circ} \mathrm{C}$. After that, the chocolate was removed from the mold and packed using aluminum foil.

The sensory analysis employed a scoring preference test by 30 untrained panelists. Panelists were asked to give their responses about their likes or dislikes on a 6-scale hedonic scale. The attributes examined in this study were color, aroma, taste, texture, and overall acceptance. This assessment was used to determine the effect of treatment variations on panelists' preferences without comparing between samples. The instrument used to measure color was the Konica Minolta CR-400 Chromameter [11]. Physical properties of hardness (hardness) were measured using ASTM D 882 Universal Testing Machine (UTM) Brand Zwick, Type DO- FB0.5ts TH. 2002 [12].

The research design used a Completely Randomized Design (CRD) pattern with one factor consisting of the concentration of Sappan wood powder $0 \%$ (control), $5 \%$ (F1), 10\% (F2), 15\% (F3). The data obtained were then analyzed statistically with the Friedman test. If there was a difference, it was continued with Duncan's Multiple Range Test (DMRT) with a significance $\alpha=5 \%$ to determine whether there was a significant difference in the quality characteristisc of the white and milk compound chocolate.

\section{Results and discussion}

\subsection{Sensory analysis}


Based on the statistical analysis of the sensory test with a significance $\alpha$ level of $=0.05$, it can be observed that there was a significant difference in the color parameters of white compound chocolate with the addition of Sappan wood powder. Table 1 showed that the average hedonic test was 4.07 (slightly like) to 5.07 (like). This condition was in line with Muhammad et al. [13] that chocolate with functional ingredients could get a high score of panelists acceptance. Sappan wood powder has a red pigment called brazilein [14], and thus it affected the color of the chocolate. According to Indriani [15], Brazilein $\left(\mathrm{C}_{16} \mathrm{H}_{14} \mathrm{O}_{2}\right)$ is a red-yellow crystal that is the pigment in the Sappan wood. Oxidized Brazilein will produce brazilein compounds that are brownish-red in color. While the milk compound chocolate with the addition of Sappan wood powder showed that there is no significant difference in color parameters with an average hedonic test value of 4.87 to 5.30 . It could be due to the very low addition of Sappan wood powder into milk compound chocolate so that it did not significantly affect the resulting color parameters [16]. Furthermore, in general, milk compound hocolate is a chocolate bar that has brown color [13], while Sappan wood powder has a red to a brownish red pigment called brazilein [14]. Therefore, the addition of Sappan wood powder into milk compound chocolate did not affect the level of consumer preference for color parameters. Table 1 showed that the most preferred sample by panelists from the color parameter was the sample without the addition of Sappan wood powder (W0, M0).

Table 1. Sensory characteristics of white and milk compound chocolate with additional of $0 \%, 5 \%$, $10 \%$, and $15 \%$ sappan wood powder (Caesalpinia sappan L.)

\begin{tabular}{|c|c|c|c|c|c|}
\hline \multirow{2}{*}{ Sample } & \multicolumn{5}{|c|}{ Value/Score } \\
\cline { 2 - 6 } & Color & Aroma & Taste & Texture & Overall \\
\hline W0 & $5.07 \pm 0.58^{\mathrm{c}}$ & $4.90 \pm 0.61^{\mathrm{b}}$ & $5.20 \pm 0.48^{\mathrm{d}}$ & $5.07 \pm 0.69^{\mathrm{c}}$ & $5.13 \pm 0.57^{\mathrm{d}}$ \\
\hline W1 & $4.07 \pm 0.78^{\mathrm{a}}$ & $4.33 \pm 0.48^{\mathrm{a}}$ & $4.33 \pm 0.61^{\mathrm{c}}$ & $4.30 \pm 0.60^{\mathrm{b}}$ & $4.30 \pm 0.53^{\mathrm{c}}$ \\
\hline W2 & $4.43 \pm 0.63^{\mathrm{b}}$ & $4.33 \pm 0.71^{\mathrm{a}}$ & $3.17 \pm 0.65^{\mathrm{b}}$ & $3.30 \pm 0.84^{\mathrm{a}}$ & $3.27 \pm 0.52^{\mathrm{b}}$ \\
\hline W3 & $4.60 \pm 0.72^{\mathrm{b}}$ & $4.10 \pm 0.66^{\mathrm{a}}$ & $2.40 \pm 0.56^{\mathrm{a}}$ & $3.07 \pm 0.98^{\mathrm{a}}$ & $2.50 \pm 0.57^{\mathrm{a}}$ \\
\hline M0 & $5.30 \pm 0.53^{\mathrm{b}}$ & $5.17 \pm 0.70^{\mathrm{b}}$ & $5.50 \pm 0.68^{\mathrm{c}}$ & $5.30 \pm 0.47^{\mathrm{d}}$ & $5.43 \pm 0.63^{\mathrm{c}}$ \\
\hline M1 & $5.20 \pm 0.71^{\mathrm{ab}}$ & $5.0 \pm 0.69^{\mathrm{b}}$ & $4.97 \pm 0.89^{\mathrm{b}}$ & $4.67 \pm 0.48^{\mathrm{c}}$ & $5.03 \pm 0.61^{\mathrm{b}}$ \\
\hline M2 & $5.07 \pm 0.64^{\mathrm{a}}$ & $4.47 \pm 0.73^{\mathrm{a}}$ & $3.93 \pm 0.83^{\mathrm{a}}$ & $3.60 \pm 0.50^{\mathrm{b}}$ & $4.61 \pm 0.94^{\mathrm{a}}$ \\
\hline M3 & $4.87 \pm 0.82^{\mathrm{a}}$ & $4.23 \pm 0.68^{\mathrm{a}}$ & $3.87 \pm 0.94^{\mathrm{a}}$ & $2.83 \pm 0.70^{\mathrm{a}}$ & $3.87 \pm 0.68^{\mathrm{a}}$ \\
\hline
\end{tabular}

a) W0 is white compound chocolate without addition of Sappan wood powder, W1 is white compound chocolate with the addition of Sappan wood powder 5\%, W2 is white compound chocolate with the addition of Sappan wood powder $10 \%$, and W3 is white compound chocolate with the addition of Sappan wood powder 15\%. M0 is milk compound chocolate without addition of Sappan wood powder, M1 is milk compound chocolate with the addition of Sappan wood powder 5\%, M2 is milk compound chocolate with the addition of Sappan wood powder 10\%, and M3 is milk compound chocolate with the addition of Sappan wood powder $15 \%$.

b) Numbers followed by different letters indicate a significant difference at $\alpha$ level of 0.05

c) Score: 1 = strongly dislike, $2=$ dislike, $3=$ slightly dislike, $4=$ slightly like, $5=$ like, $6=$ strongly very.

In the attributes of aroma, the result showed that there was a significant difference in the aroma of white compound chocolate with the addition os Sappan wood powder compared to samples without the addition of Sappan wood powder (W0). The addition of Sappan wood powder to white compound chocolate with concentrations of 5\% (W1), 10\% (W2), and $15 \%$ (W3) affected the aroma characteristics of the white compound chocolate produced. Based on the sensory test with a significance $\alpha$ level of $=0.05$ Table 1 showed that there is no significant difference in the parameters of the aroma of milk compound chocolate. However, the addition of Sappan wood powder by $10 \%$ (M2) and 15\% (M3) produced a distinctive aroma compared to milk compound chocolate with the addition of Sappan wood powder at $0 \%$ (M0) and 5\% (M1). The significant differences between samples W1, W2, and W3 indicated that the aroma in each sample affected the panelists' preference for the sample. The difference in the aroma was due to the characteristic aroma 
of Sappan wood. The content of essential oils in Sappan wood such as D- $\alpha$-phellandrene, gallic acid, osinema, and resin gave a distinctive aroma to Sappan wood [17].

In the parameter of taste, there was a significant difference between the taste of white and milk compound chocolate samples with the addition of Sappan wood powder. Panelists' assessment of white compound chocolate ranged from 2.40 to 5.20. While the panelists' assessment of the taste of milk compound chocolate ranged from 3.87 to 5.50. The formula with the addition of Sappan wood powder by $15 \%$ (W3, M3) was the least preferred sample by the panelists. The higher the concentration of Sappan wood powder added to the white and milk compound chocolates, the less the taste of the samples. It might be caused by a bitter taste as a result of addition higher concentration Sappan wood powder. The bitter taste was due to the saponins and tannins content in the Sappan wood [18].

Similiar to the taste, there was a significant difference between the white and milk compound chocolate samples. Panelists' assessment of the texture of the white compound chocolate sample ranged from 3.07-5.07 while the milk compound chocolate ranged from 2.83-5.30. The formula with the addition of $10 \%$ and $15 \%$ Sappan wood powder was the least preferred sample by the panelists because it had least score (2-3 is slightly dislike and dislike). It might because by a sandy texture. It was due to the size of the Sappan wood powder used was 120 mesh and the mixing time in the melanger was 2.5 hours. The chocolate paste refining process was done until the particle size was $<30 \mathrm{~m}$ (400 mesh) [19]. However, the mixing time that exceeds 2.5 hours in the melanger resulted in temperature fluctuations $\left(39-40^{\circ} \mathrm{C}\right)$, which can cause blooming in chocolate [20]. Moreover, Sappan wood contains $15-35 \%$ cellulose and lignin that causes the wood to become hard [21].

The variance results showed that the addition of Sappan wood powder concentration had a significant effect $(\mathrm{P}<0.05)$ on the hedonic test of the overall acceptance of white and milk chocolate compounds. Table 1 showed that the average value of the hedonic test for white compound chocolate was 2.50 (dislike) to 5.15 (like) while the milk compound chocolate has an average value of 3.87 (slightly like) to 5.43 (like). The average value of the overall preference showed that white and milk compound chocolate with the addition of Sappan wood powder can be accepted quite well by the panelists. The overall reception was influenced by color, taste, and texture.

\subsection{Color analysis}

Table 2. Results of color testing with chromameter on white and milk compound chocolate with addition of $0 \%, 5 \%, 10 \%$, and 15\% Sappan wood powder (Caesalpinia sappan L.)

\begin{tabular}{|c|c|c|c|c|}
\hline \multirow{3}{*}{ Chocolate Type } & $\begin{array}{c}\text { Sappan Wood } \\
\text { Powder } \\
\text { Concentration }\end{array}$ & Lightness & $\mathbf{a}^{*}$ & $\mathbf{b}^{*}$ \\
\hline \multirow{3}{*}{$\begin{array}{c}\text { White } \\
\text { Compound } \\
\text { Chocolate }\end{array}$} & $0 \%(\mathrm{~W} 0)$ & $86.62 \pm 0.25^{\mathrm{d}}$ & $-5.87 \pm 0.06^{\mathrm{a}}$ & $19.51 \pm 0.33^{\mathrm{c}}$ \\
\cline { 2 - 5 } & $5 \%(\mathrm{~W} 1)$ & $44.54 \pm 0.19^{\mathrm{c}}$ & $10.43 \pm 0.08^{\mathrm{d}}$ & $19.22 \pm 0.29^{\mathrm{c}}$ \\
\cline { 2 - 5 } & $10 \%(\mathrm{~W} 2)$ & $36.75 \pm 0.69^{\mathrm{b}}$ & $10.16 \pm 0.06^{\mathrm{c}}$ & $16.39 \pm 0.41^{\mathrm{b}}$ \\
\hline \multirow{3}{*}{$\begin{array}{c}\text { Milk Compound } \\
\text { Chocolate }\end{array}$} & $15 \%(\mathrm{~W} 3)$ & $33.00 \pm 0.21^{\mathrm{a}}$ & $9.20 \pm 0.05^{\mathrm{b}}$ & $13.48 \pm 0.10^{\mathrm{s}}$ \\
\cline { 2 - 5 } & $0 \%(\mathrm{M} 0)$ & $36.04 \pm 0.27^{\mathrm{d}}$ & $8.37 \pm 0.08^{\mathrm{d}}$ & $13.32 \pm 0.14^{\mathrm{d}}$ \\
\cline { 2 - 5 } & $10 \%(\mathrm{M} 1)$ & $32.16 \pm 0.28^{\mathrm{c}}$ & $7.75 \pm 0.03^{\mathrm{c}}$ & $11.26 \pm 0.12^{\mathrm{c}}$ \\
\cline { 2 - 5 } & $15 \%(\mathrm{M} 3)$ & $31.02 \pm 0.32^{\mathrm{b}}$ & $7.20 \pm 0.05^{\mathrm{b}}$ & $10.01 \pm 0.22^{\mathrm{b}}$ \\
\hline
\end{tabular}

Information:

Numbers followed by different letters indicate a significant difference at the $\alpha$ level of 0.05

Table 2 showed the values of $\mathrm{L}^{*}, \mathrm{a}^{*}, \mathrm{~b}^{*}$ in white and milk compound chocolate. The variance results showed that the addition of Sappan wood powder concentration had a 
significant effect on the intensity of the values of $\mathrm{L}^{*}, \mathrm{a}^{*}$, and $\mathrm{b}^{*}(\mathrm{P}<0.05)$. The average intensity of the $\mathrm{L}^{*}$ value produced by white and milk compound chocolates were between 33.00-86.62 and 29.50-36.04, respectively. Table 2 showed a negative correlation between the addition of Sappan wood powder to the $\mathrm{L}^{*}$ value, the greater the Sappan wood powder concentration, the smaller the $\mathrm{L}^{*}$ value and the darker the resulting chocolate. Brightness is the basic color spectrum, the addition of other colors to an object will decrease the brightness value [22]. The hedonic test showed that the sample with 0\% Sappan wood powder (W0, M0) was preferred by the panelists compared to other samples. It showed that the panelists preferred chocolate samples with higher brightness values.

The intensity of the $\mathrm{a}^{*}$ value of white compound chocolate color without the addition of Sappan wood powder (W0) has a value of $a^{*}-5.87$, while the formula with the addition of Sappan wood powder concentration of $5 \%, 10 \%$, and $15 \%$ had an $a^{*}$ value ranging from 9.20-10.43 meaning that it tended to be red. The milk compound chocolate sample had an average intensity of $\mathrm{a}^{*}$ value ranging from 6.61 to 8.37 . Table 2 showed a negative correlation between the treatment of adding Sappan wood powder to the $a^{*}$ value, the higher the concentration of Sappan wood powder added, the smaller the a* value produced. The sensory test Table 1 showed that the panelists preferred the sample without the addition of Sappan wood (W0 and M0). It showed that the panelists preferred white compound chocolate samples with lower red intensity. While in the milk compound chocolate sample, the panelists preferred the sample with a higher red intensity. The difference in the a* value of the white and milk compound chocolate samples with the addition of Sappan wood powder was caused by the anthocyanin content in the Sappan wood to produce a red pigment [23]. Moreover, the content of brazilein in Sappan wood caused a red color. Oxidized Brazilein will produce brazilein compounds that have brownish-red color [15].

The $b^{*}$ value of white compound chocolate ranged from 13.48 to 19.51 while the milk compound chocolate ranged from 9.09 to 13.32. The addition of Sappan wood powder with a concentration of $0 \%$ (W0, M0) showed the highest number of yellow color intensity and in the hedonic test. Table 1 showed that the panelists preferred sample without the addition of Sappan wood powder (W0, M0). It showed that the panelists preferred white and milk compound chocolate with a more yellow color. Table 2 showed a negative correlation between the amount of Sappan wood powder concentration and the $b^{*}$ value, the greater the Sappan wood powder concentration, the smaller the $b^{*}$ value produced. Brownish-yellow to reddish-brown color was due to the flavonoid tannin content in Sappan wood [24].

\subsection{Hardness analysis}

The observation results of the intensity of the Fmax value of white compound chocolate ranged from 110.73 to 126.03 while the milk compound chocolate ranged from 120.52 to 135.69. The addition of Sappan wood powder with a concentration of $0 \%(\mathrm{M} 0)$ and $5 \%$ (W1) showed the lowest Fmax value. The analysis of variance results showed that the addition of Sappan wood powder concentration had a significant effect on the Fmax value $(\mathrm{P}<0.05)$. Table 3 shows a positive correlation between the amount of Sappan wood powder concentration and the Fmax value, the greater the Sappan wood powder concentration, the greater the resulting Fmax value. It showed that the addition of Sappan wood powder into white and milk compound chocolate affected the hardness of the resulting chocolate. If the force required to change the shape of a material is greater, the material is getting harder [18]. Results obtained in this study confirmed that the addition of herbs and spices can significantly the quality of cocoa-derived products, including chocolate and cocoa drink $[25,26,27]$. 
Table 3. Fmax test results on white and milk compound chocolate with addition of Sappan wood powder (Caesalpinia sappan L.)

\begin{tabular}{|c|c|c|}
\hline Chocolate Type & $\begin{array}{c}\text { Sappan Wood Powder } \\
\text { Concentration }\end{array}$ & $\begin{array}{c}\mathbf{F}_{\max } \\
\text { (N) }\end{array}$ \\
\hline \multirow{3}{*}{$\begin{array}{c}\text { White Compound } \\
\text { Chocolate }\end{array}$} & $0 \%(\mathrm{~W} 0)$ & $114.29 \pm 1.37^{\mathrm{a}}$ \\
\cline { 2 - 3 } & $5 \%(\mathrm{~W} 1)$ & $110.73 \pm 2.33^{\mathrm{a}}$ \\
\cline { 2 - 3 } & $10 \%(\mathrm{~W} 2)$ & $123.59 \pm 1.76^{\mathrm{b}}$ \\
\hline \multirow{3}{*}{$\begin{array}{c}\text { Milk Compound } \\
\text { Chocolate }\end{array}$} & $15 \%(\mathrm{~W} 3)$ & $126.03 \pm 5.90^{\mathrm{b}}$ \\
\cline { 2 - 3 } & $0 \%(\mathrm{M} 0)$ & $120.52 \pm 3.80^{\mathrm{a}}$ \\
\cline { 2 - 3 } & $5 \%(\mathrm{M} 1)$ & $129.86 \pm 4.83^{\mathrm{ab}}$ \\
\cline { 2 - 3 } & $10 \%(\mathrm{M} 2)$ & $130.38 \pm 8.13^{\mathrm{ab}}$ \\
\hline
\end{tabular}

Numbers followed by different letters indicate that there is a significant difference in the $\alpha$ level of 0.05

\section{Conclusion}

Based on the research results, it was concluded that the addition of Sappan wood powder could reduce the panelists' preference for all parameters, decrease the chocolate brightness, and increase the chocolate hardness. Morever, the panelists preferred white and milk compound chocolate without the addition of Sappan wood powder for all parameters. Therefore, it is necessary to improve the physical and sensory analysis of white and milk chocolate with the addition of Sappan wood powder so that it have not significantly different quality with white and milk chocolate control (without the addition of Sappan wood powder). For example, encapsulation of oleoresin Sappan wood into white and milk compound chocolate.

This research was financially supported by Penelitian Perguruan Tinggi Badan Hukum (PTN BH) Skema Penelitian Unggulan Terapan (No. 221.1/UN27.22/HK.07.00/2021)

\section{References}

1. D. Praseptiangga, J.M.G. Zambrano, A.P. Sanjaya, D.R.A. Muhammad, D. R. A. AIMS Agric. Food 5, 1 (2020)

2. Badan Pusat Statistik Produksi Tanaman Perkebunan Menurut Propinsi dan Jenins Tanaman. (BPS, Jakarta, 2019)

3. Departemen Perindustrian. Gambaran Sekilas Industri Kakao (Deperindag, Jakarta, 2007)

4. S. Ramidah. J.Industri Has. Perkeb 11,1 (2016)

5. International Trade Center. List of Product Exported by Indonesia: Cocoa and Cocoa Preparation (2019)

6. D.R.A. Muhammad, D. Praseptiangga, D. Van de Walle, K Dewettinck. Food Chem. 231 (2017)

7. P.E. Aikpokpodion, L.N Dongo. International J. of Sustainable Crop. Production 5, 4 (2010).

8. J. Towaha. SIRINOV 2, 1 (2014)

9. Neswati, S.D. Ismanto, S. Teknologi Pertanian 22, 2 (2018)

10. S. Kumar, Pandey A.K. Sci. World J (2013) 
11. F. Indrayati, R. Utami,E. Nurhartadi. J. Teknosains Pangan 2, 4 (2013)

12. I. Muflihati, Lukitawesa, B.Narindri, Afriyanti, R. Mailia. Efek Substitusi Tepung Terigu dengan Pati Ketan terhadap Sifat Fisik Cookies (Seminar Nasional Universitas PGRI Yogyakarta, Yogyakarta, 2015)

13. D.R.A. Muhammad, F. Zulfa, D. Purnomo, C. Widiatmoko, D.L.N. Fibri. IOP Conference Series: Earth and Environmental Science 637, 1 (2021)

14. Najarudin, Tamrin, N. Asyik. J.Sains dan Teknologi Pangan 3, 1 (2018)

15. H. Indriani. Stabilitas Pigmen Alami Kayu Secang (Caesalpinia sappan L.) dalam Model Minuman Ringan (Institut Pertanian Bogor, Bogor, 2003)

16. D. Praseptiangga, Y. Nabila,D.R.A. Muhammad.J. of Sustainable Agriculture 33, 1 (2018)

17. D.R. Thoyibi, A. S. Duniaj.,I.K. Suter. J.Ilmu dan Teknologi Pangan 8, 4 (2019)

18. A. Puspitasari, Arum. Pengaruh Penambahan Ekstrak Secang (Caesalpinia sappan L,) terhadap Kualitas Dodol Garut (Universitas Sebelas Maret, Surakarta, 2012)

19. S. Mulato, S. Widyotomo, H. Nur'aini.Kinerja Alat Penghalus Pasta Cokelat Tipe Silinder Berputar (Pusat Penelitian Kopi dan Kakao, Jember, 2004)

20. Fahrurrozi, P. Lisdiyanti, S. Ratnakomala, S. Fauziyyah, M.N. Sari. Teknologi Fermentasi dan Pengolahan Biji Kakao (LIPI Press, Jakarta, 2020)

21. N.S. Hartati,E. Sudarmonowati,Suharson, K. Sofyan. Widyariset 14, 3 (2011)

22. B. Satriyant, S.B. Widjanarko, Yunianta. J. Teknologi Pertan. 13, 3 (2012)

23. Y. Karlina, P. Adirestuti, D. M. Agustini, N.L. Fadhillah, N. Fauziyyah, D. Malita Chemica se Nat.N.A 4, 2 (2016).

24. E. Kamudjiastuti. Maj.Kulit Karet dan Plastik 30, (2009).

25. D.R.A. Muhammad, J.E. Kongor, K. Dewettinck, K. J. Food Sci. Technol. 58, 10 (2021)

26. D.R.A. Muhammad, E. Tuenter, G.D. Patria, K. Foubert, L. Pieters, K. Dewettinck, Food Chem. 340, 127983 (2021)

27. D.R.A. Muhammad, V. Lemarcq, E. Alderweireldt, P. Vanoverberghe, D. Praseptiangga, J.G. Juvinal, K. Dewettinck. J. Food Sci. Technol. 57, 5 (2020) 